\title{
An Improved Method for Intrathecal Catheterization in the Rat
}

\author{
Young Chan Jeong and Young Bae Kwon* \\ Department of Pharmacology, Institute for Medical Science, Chonbuk National University Medical School, Jeonju, Korea
}

\begin{abstract}
Catheterization of the subarachnoid space provides a useful tool to deliver drugs to spinal cord in rat. However, the passage of a long intrathecal catheter inserted via the cisterna magnum to lumbar spinal levels increases the risk of spinal cord trauma and the mislocation of catether into other places. Thus, present study was aimed to introduce direct subarachnoid catheterization of the rat lumbar spinal cord with novel shape of catheter. An intrathecal PE-10 catheter was fabricated with coil (four-time helix with $2 \mathbf{~ m m}$ diameter) on either end and attached small silicon beads on both end of the coil. Using the silicon bead at insertion part as an anchorage, the catheter was advanced into the subarachnoid space until the silicon bead was embedded on a drilled hole over interspinous space between L4 and L5 vertebra. And then, silicon bead was tightly attached by surgical glue and dental resin with vertebra. Using the other side of silicon bead, catheter was tightly suturing with muscle layer. Finally, external portion of the catheter was placed into stainless steel protector on neck to reduce the damage by rat. Following this catheterization, it is not significantly affect the general physiology (i.e. motor function, weight gain and mechanical allodynia) of the rat without catheter loss over 2 weeks. Moreover, intrathecal injection either fluorescent dye or lidocaine further confirmed that drug diffusion site was appropriated for intended target.
\end{abstract}

Key words: Intrathecal, catheter, lumbar, lidocaine, silicon bead

Received 10 November 2010; Revised version received 30 November 2010; Accepted 3 December 2010

척수강내 투여법(intrathecal injection)은 지주막하공간 (subarachnoid space)의 뇌척수액 내로 약물을 직접적으로 투여하는 방법이다. 임상적으로 중추 신경계에 선택적으 로 작용하는 약물의 경우 척수강내 투여는 전신 투여 (systemic injection)시의 부작용을 감소시킬 뿐만 아니라 뇌혈관장벽(brain-blood barrier)의 투과성이 낮은 약물에 대해 최대 치료효과(maximal therapeutic efficacy)를 유도 할 수 있어 널리 이용되고 있다. 예로 모르핀을 척수강 내로 투여하면 경구 투여용량의 약 $1 / 300$ 로 동일한 진통 효과를 나타낼 수 있어 운동기능 및 자율신경 기능장애 등의 부작용을 최소화할 수 있다(Nahm and Kim, 2009). 전임상 연구에서 척수강내 투여법은 다양한 표적의 약 물들에 대한 척수내 작용양상 및 효과를 규명하는데 유 용하다(Storkson et al., 1996). 실험동물을 이용한 척수강 내 투여법은 크게 비침습적인 직접투여법(direct injection method)과 수술을 통한 카테터 삽입법(cannulation

*Corresponding author: Young Bae Kwon, Department of Pharmacology, Institute for Medical Science, Chonbuk National University Medical School, 664-14 Deokjin-dong, Jeonju, Jeonbuk 561-756, Korea

Tel: $+82-63-270-3088$

Fax: +82-63-275-2855

E-mail: 1972y@jbnu.ac.kr dwelling method)으로 나눈다. 직접투여법은 척수강내로 주사바늘을 삽입하여 약물을 주입하는 방법이다(Hylden and Wilcox, 1980). 직접투여법은 동물의 스트레스를 거 의 주지않고 수술 후 회복기간도 필요없지만, 성공적인 약물투여를 위해 실험자의 숙련을 요구하며 반복적인 투 여에도 제한이 따른다. 카테터 삽입법은 폴리에틸렌 카테 터(PE10)를 환추후두막(atlanto-occipital membrane)으로부 터 제1-2번 요수(dorsal lumbar spinal cord)의 지주막하 공간까지 삽입하는 방법이다(Yaksh and Rudy, 1976). 이 러한 카테터 삽입법은 장기간 동안 안정적으로 척수강내 약물투여를 가능하게 하였다(Storkson et al., 1996). 그러 나, 척수강내로 삽입한 카테터가 쉽게 빠져서 수술 후 4 일 이내에 $50 \%$ 이상의 동물에서 소실되는 문제점이 있 다(Milligan et al., 1999). 또한, 카테터를 환추후두막에서 요수부위까지 삽관하는 과정에서 척수의 손상, 압박 및 신경 다발의 손상을 초래하여 다양한 행동반응의 장애가 생기기도 한다(Martin et al., 1984). 일부에서는 지주막하 공간 이외로 카테터가 위치되는 현상이 빈번히 관찰되었 으며(Asato et al., 2001), 뇌척수액의 누수현상으로 인하 여 수술 후 사망률이 높았다(Tsang et al., 1997). 또한 수 술 후 현저한 체중손실로 인해 실험이 불가능한 경우까 지 발생하였다(Serpell et al., 1993). 


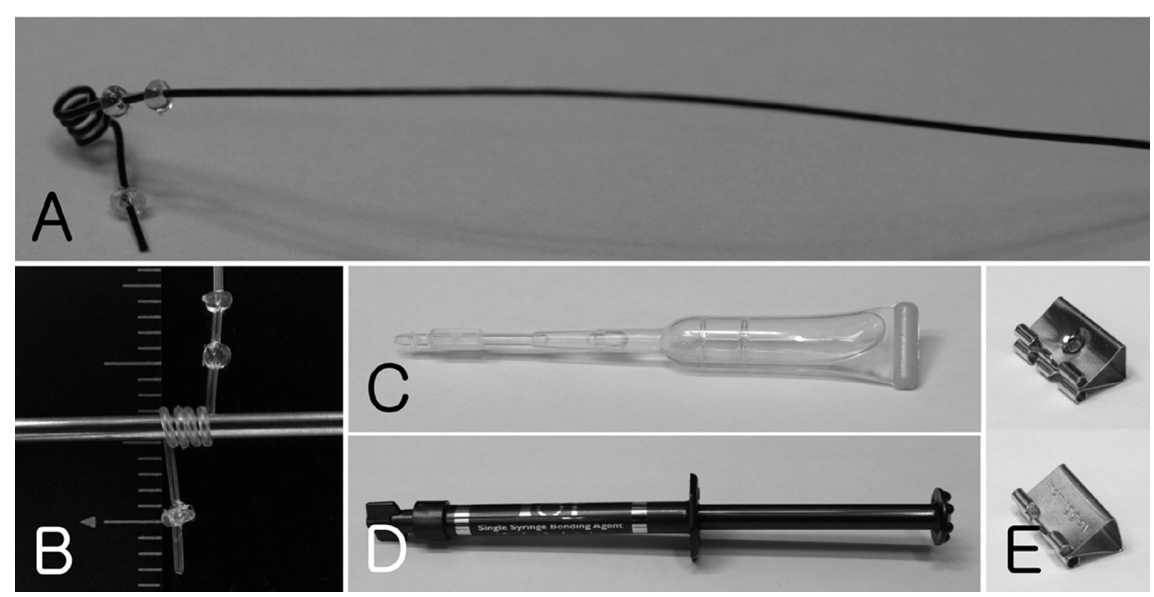

Figure 1. The preparation of intrathecal catheter. (A) Shape of catheter. (B) Fabrication of four helix and location of silicon bead. (C) Surgical glue for silicon bead and catheter. (D) Dental resin for silicon bead and catheter. (E) Catheter protector.

이러한 수술적인 문제점을 극복하기 위하여 다양한 방 법이 시도되고 있으나 근본적인 문제점이 완전히 개선되 지 않고 있다(Dib, 1984; Martin et al., 1984). 수술시 부작용의 주요한 이유는 상대적으로 지주막하 공간이 좁 은 경팽대부(cervical enlargement)를 통과하는 과정에서 발생한다. 따라서, 본 연구에서는 요수부위로 직접 카테 터를 삽입하여 이러한 문제점을 극복하는 새로운 수술법 을 제시하고자 하고, 카테터의 손실을 최소화할 수 있는 기법을 제시하고자 한다.

\section{재료 및 방법}

\section{실험동물}

체중이 250 280 g이 되는 Sprague-Dawley 랫드는 대 한 바이오링크에서 통해 구입하여, 7일간 적응시킨 다음 실험에 사용하였다. 실험동물실의 환경은 표준적인 사육 조건으로서 온도는 $23 \pm 2{ }^{\circ} \mathrm{C}$, 습도는 $40-60 \%$, 명암 주기 는 12시간으로 유지되었으며, 사료와 음수는 제한없이 공 급하였다 실험동물은 실험동물의 관리 및 실험과정은 전 북대학교 실험동물 윤리위원회의 승인을 받은 후 규정에 따라서 수행하였다.

\section{카테터의 준비}

$18 \mathrm{~cm}$ 의 PE10 튜브(Becton Dickinson and Company, City, USA)의 $5 \mathrm{~cm}$ 되는 지점에서 직경 $2 \mathrm{~mm}$ 의 stainless $\operatorname{rod}$ 를 이용하여 반시계 방향으로 4바퀴를 감아주고 테이 프로 고정시킨 뒤 $75^{\circ} \mathrm{C}$ 물에 20초간 담근 뒤 꺼내어 완 충 스프링을 성형한다(Figure $1 \mathrm{~A})$. 카테터의 길이가 긴 부 분의 스프링에서 $3 \mathrm{~mm}$ 와 $7 \mathrm{~mm}$ 지점에 글루건을 이용하 여 직경 $1 \mathrm{~mm}$ 정도의 실리콘 볼(silicon bead)을 각각 만 들어 준다. 반대편 카테터는 척수내로 삽입할 부위로 스 프링 말단에서 $5 \mathrm{~mm}$ 지점에 실리콘 볼을 만들고 말단에
서 $3 \mathrm{~mm}$ 의 카테터만 남도록 잘라 준다(Figure 1B). 카테 터는 70\% 알코올에 하루 정도 담가 두고 수술 전 30분 에 식염수로 세척한 후 사용하였다.

\section{접착제 및 카테터 보호클립}

카테터를 고정시키기 위해서 체액이 존재하여도 생체 와 카테터를 접착시키기 위해 수술용 접착제(Figure 1C) 와 치과용 레진(PQ1, Ultradent, City, USA, Figure 1D) 을 사용하였다.

카테터 보호클립은 카테터의 노출부위를 보호하여 손 실을 줄이기 위한 용도로 사용된다. 가로 $(23 \mathrm{~mm}) \times$ 세로(10 $\mathrm{mm}) \times$ 높이 $(15 \mathrm{~mm})$ 의 삼각형모양의 철재클립의 한쪽 면에 구멍을 뜷어서 준비하였다(Figure 1E).

\section{카테터 삽입수술법}

랫드에 ketamine $(90 \mathrm{mg} / \mathrm{kg}$ )과 xylazine $(9 \mathrm{mg} / \mathrm{kg}$ )을 복강내 에 주사하여 마취하였다. 마취 후 피부를 세로로 절개한 후 요추 4번과 5 번 사이의 근육을 가로로 $1 \sim 1.5 \mathrm{~cm}$ 절개하고 근육을 제거하였다. 실체현미경(Seiler Precision Microscopes, City, USA)을 이용하여, 요추 4-5번 사이의 경뇌막(dura matter)이 보이면, 바늘을 이용하여 작은 구멍을 뜷어 주었 다. 이때 뇌척수액의 유출을 확인한 후 준비해 두었던 카 테터를 삽입하여 실리콘 볼이 닿을 때까지 밀어 넣었다 (Figure 2A). 그리고 수술용 접착제를 이용하여 실리콘 볼과 요추를 접착시키고 치과용 레진을 그 위에 도포하여 강력 하게 고정해 주었다. 완충 스프링부위와 첫번째 실리콘 볼 부분까지 근육내로 넣고 두번째 볼 사이의 근육을 봉합하 였다(Figure 2B). $18 \mathrm{G}$ 주사침을 이용하여 목 부분의 등쪽 외피 정준선에 구멍을 내고 카테터를 넣어 빼내었다(Figure 2C). 수술부의 피부를 봉합하였다. 카테터는 보호크립 속으 로 넣어 주고 보호크립은 나일론 봉합사를 이용하여 단단 히 고정시킨 후 솜으로 입구를 막아 주었다(Figure 2D). 


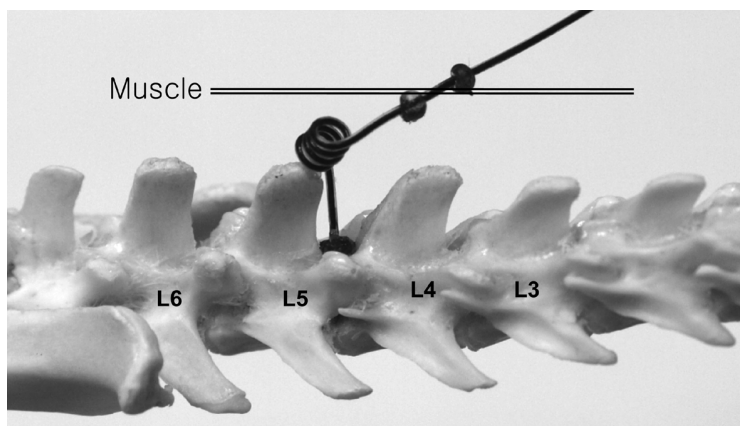

A
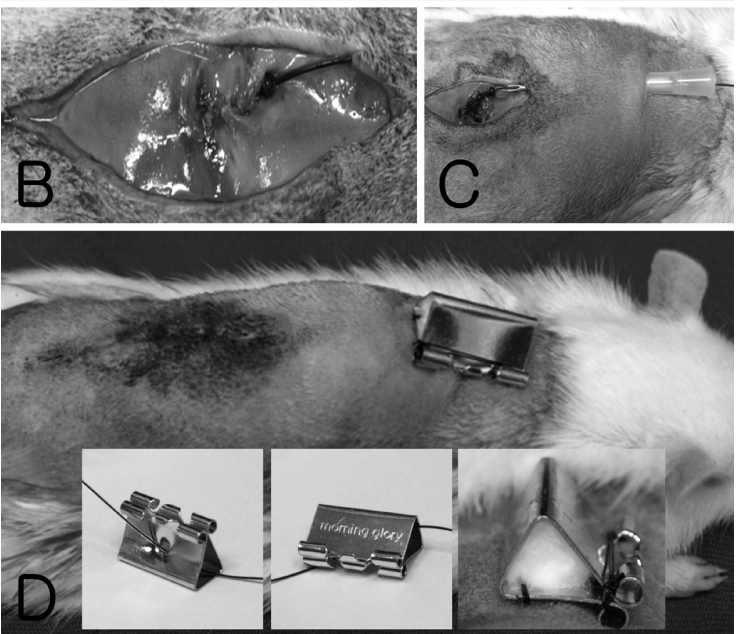

Figure 2. Surgical procedures. (A) Diagram for the catheter insertion. (B) Catheter was tied with muscle using silicon bead. (C) Catheter extruded into neck area by 18 gage needle. (D) Catheter protector attached into skin and hide by cotton.

\section{수술 후 검사}

1) 관능 검사: 회복기간 동안 동물의 행동, 체중의 변 화, 배뇨 및 배변장애 등을 관찰하였다.

2) 카테터 건전성 평가: 수술 후 카테터의 소실유무등 을 평가하였다.

3) 척수손상 검사: 카테터에 의한 척수손상시 동반되는 통증인 mechanical allodynia를 측정하였다. 철망위에 원 기둥모양의 아크릴관 $(20 \mathrm{~cm} \times 20 \mathrm{~cm} \times 20 \mathrm{~cm})$ 에서 일정시간 적응 후 von Frey filament $(2,4,6,8$, 및 $15 \mathrm{~g})$ 에 대 한 발바닥 회피반응(paw withdrawal response)를 측정하 여 통증역치를 평가하였다.

4) 형광물질의 척수강내 투여를 통한 약물분포: 형광물 질인 cy3가 표지된 항체(Jackson Immunoresearch, City, USA)를 $7.5 \mu \mathrm{g} / 50 \mu \mathrm{L}$ 농도로 희석하여 카테터를 통하여 $50 \mu \mathrm{L}$ 를 주입한 후 무효공간에 $10 \mu \mathrm{L}$ 의 뇌척수액을 투여 하였다. 30분 후 랫드에 ketamine $(90 \mathrm{mg} / \mathrm{kg}$ )과 xylazine $(9 \mathrm{mg} / \mathrm{kg})$ 를 복강내에 주사하여 마취하고 충분한 의식 소 실을 확인한 후 척추를 분리하여 요수를 적출하였다. 척 수를 OCT compound를 이용하여 급속 냉동시킨 후 40
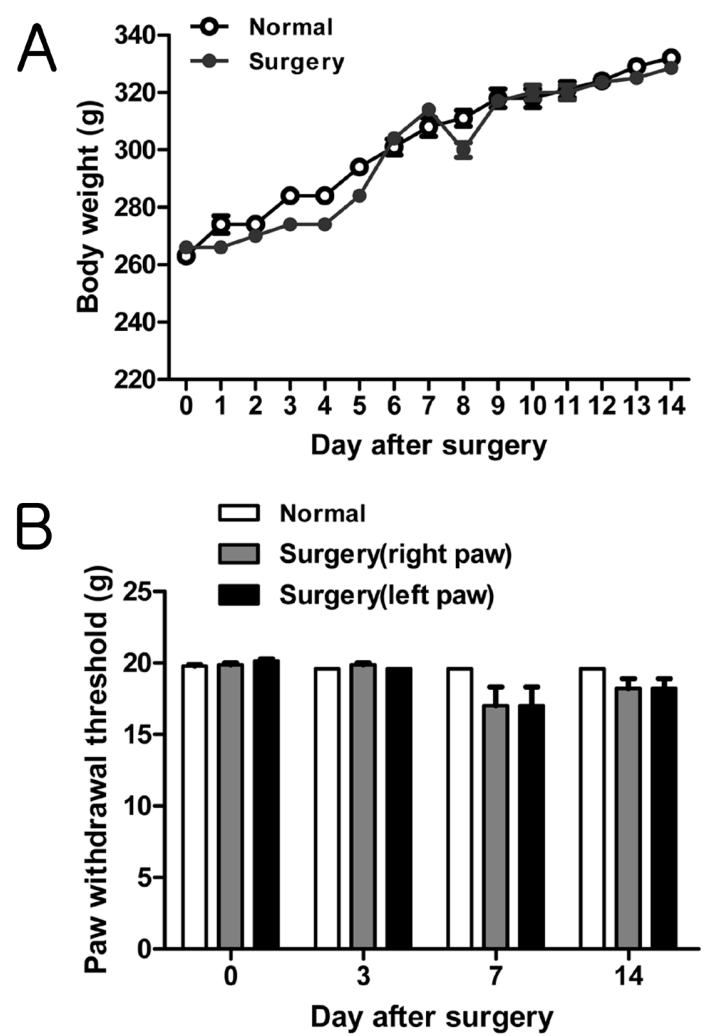

Figure 3. The body weight gain $(A)$ and mechanical allodynia by von Frey filament $(B)$ after catheterization for 2 weeks. Each group contains 10 rats.
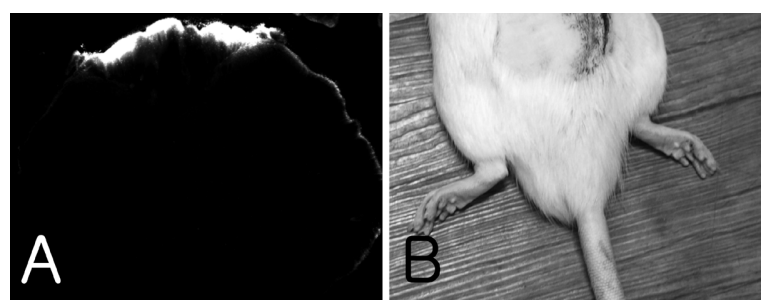

Figure 4. The intrathecal drug infusion test. (A) Intrathecal injection of fluorescent dye cy3 was bilaterally located into surface of lumbar spinal cord. (B) Intrathecal injection of lidocaine bilaterally blocked sensory and motor function of hind limb.

$\mu \mathrm{m}$ 절편을 만든 후 형광 현미경을 통하여 형광물질의 분 포위치를 관찰하였다.

5) 국소마취제의 척수강내 투여를 통한 행동평가: 카테 터에 Hamilton syringe를 연결한 다음, $2 \%$ lidocaine 50 $\mu \mathrm{L}$ 투여하고, 무효공간의 양을 채우기 위하여 인공 뇌척 수액을 $10 \mu \mathrm{L}$ 투여하였다. Lidocaine 투여 후 뒤 쪽 양발 의 운동기능 소실을 평가하고 paw flinch를 통해 감각기 능의 마비를 검사하였다.

\section{통계처리}

결과는 Mean $\pm \mathrm{SD}$ 값으로 표기하였다. 자료를 통계학적 
으로 유의한 수준으로 분석하기 위하여 GraphPad Prism 4.0 (GraphPad Software, San Diego, USA)을 이용하여, one-way ANOVA로 분석하였고, 정상군과 실험군 간의 차 이를 비교하기 위하여 Newman-Keuls multiple comparison test를 이용하여 사후분석을 실시하였다.

\section{결 과}

데이터에는 명시하지 않았지만 수술에 사용된 10마리 의 랫드에서 사망한 예는 없었으며, 기본적인 행동양식의 변화(자해 현상, 운동성 감소, 뒷다리 마비)가 관찰되지 않았다. 또한, 척수손상에 따른 배변배뇨 이상 및 뇌척수 압 증가에 따른 눈물흘림현상(lacrimation)이 나타나지 않 았다. 수술 후 체중증가는 정상동물과 비교하여 현저한 차이를 보이지 않았다(Figure 3A). 카테터 보호클립으로 인해 동물에서 카테터가 4주 이상 소실없이 유지되었다. 카테터의 척수손상시 나타날 수 있는 이질통(allodynia) 여부를 von Frey filament로 측정한 결과 정상동물과 비 교하여 2주간 유의한 차이가 나타나지 않았다(Figure 3B). 카테터 내로 형광 염료를 주입 후 척수 내에서의 분포를 살펴본 결과, 척수표면에 양측성으로 분포함을 확인하였 다(Figure 4A). 이는 척수의 손상없이 약물이 지주막하 공 간에 선택적으로 분포되었음을 시사한다. 뿐만 아니라, 국 소마취제인 lidocaine을 척수내로 투여하였을 때 10-20초 이내에 양쪽 발의 운동성 및 감각이 소실되었으며, 20 분 정도까지 유지되는 것이 모든 동물에서 관찰되었다(Figure 4B).

\section{고 찰}

랫드에서 척수강내 약물투여를 위해 기존 방법인 카테 터를 환추후두막에서 지주막하 공간이 좁은 경팽대부를 통과하여 요수로 삽입하는 과정에서 다양한 문제점이 발 생하였다. 첫째, 삽관과정에서 척수손상 등의 문제점으로 인한 동물의 행동학적인 장애가 유발되었다(Martin et al., 1984; Tsang et al., 1997). 둘째, 카테터를 삽입할 때 척 수의 등쪽 정중선부위의 지주막하공간에 카테터가 위치 되어야 하지만 측면이나 배측에 위치하는 경우가 많아서 약물의 투여시 양측성으로 작용하지 않고 편측성으로 작 용하는 경우가 많았다(Asato et al., 2001). 마지막으로 삽 입된 카테터가 유지되지 않고 소실되는 경우가 많았다 (Milligan et al., 1999). 본 연구는 랫드에서 척수내 약물 투여를 위해 지주막하공간으로 카테터를 삽관하기 위한 새로운 기술로 기존방법들의 단점을 극복하기 위해 수행 되었다.

본 연구에서는 경팽대부를 경유하지 않고 카테터를 4
번 요추와 5번 요추의 척추 간극 사이로 삽입하는 방법 을 시행하였다. 이때 척추내로 삽입되는 카테터의 길이를 $3 \mathrm{~mm}$ 로 최소화시킴으로서 척수손상의 가능성을 최소화 하였다. 또한, 실체현미경을 통하여 요추 4 번과 5 번 사이 의 척추간극으로 작은 구멍을 ㄸㄸㅀㅇㅓ 카테터를 직접 삽입 하고 실리콘 볼로 막은 다음 접착제로 밀봉함으로써 뇌 척수액의 손실을 최소화하였다. 그 결과 기존의 삽관법에 서 관찰되었던 배뇨, 배변 장애 및 눈물흘림 현상 등이 나타나지 않았다. 또한 뒷다리가 마비되거나 체중이 되는 등의 문제점도 나타나지 않았다. 이는 기존의 환추후두막 삽관법시 $15 \%$ 이상의 비율로 관찰된 증상인 수술후 사 망, 뇌척수액 유출, 후지 마지, 체중증가 지연 및 방광기 능 장애 등의 문제점이 개선된 것으로 판단된다(Poon et al., 2005).

중요하게는 척수의 손상으로 유발되는 이질통이 수술 후 모든 개체에서 관찰되지 않아 척수의 압박이나 손상 이 없음을 최종적으로 확인하였다. 또한, 본 연구에서 삽 입하는 방식에 의해 약물은 정중선 부위의 지주막하 공 간에 정확하게 분포함을 형광염료를 통해서 명확히 확인 하였다. 뿐만 아니라, lidocaine 투여시 양측성으로 뒷다 리의 운동 및 감각소실이 15초 이내로 나타나서 20-30 분간 지속되었다. 이는 척수강내 약물의 투여에 적합한 위치에 카테터의 삽관이 이루어졌음을 시사하였다.

카테터 삽입시 가장 중요한 것은 카테터의 삽입과 고 정력을 높이고 피부 밖으로 노출되는 카테터를 랫드가 손 상시키지 않도록 보호하는 것이다(Xu et al., 2009). 이를 위해 카테터를 $60^{\circ} \mathrm{C}$ 의 물에 넣고 카테터 한쪽을 잡고 늘 려 직경을 줄임으로써 카테터 삽입을 용이하게 하거나 카 테터에 bead를 만들어 근육내 고정력을 높일 수 있다 (Storkson et al., 1996). 그러나 이러한 방법으로도 수술 후 동물에 의해 카테터가 소실되어 실험을 유지할 수 없 는 경우가 다수 발생하였다(Milligan et al., 1999). 본 연 구에서는 카테터의 삽입된 척수부위에 내부적으로는 접 착제로 실리콘 볼과 요추를 단단히 밀착시키고 랫드의 움 직임시에 나타나는 인장강도를 용수철 모양의 카테터로 흡수시켰다. 또한, 외부에 위치한 카테터는 철제클립 안 으로 카테터를 보호하여 랫드의 앞발, 뒷발 및 이빨 등 으로 야기되는 직접적인 카테터 손상을 막을 수 있었다. 이러한 결과 수술 후 4주 이상 관찰하였을 때도 카테터 가 소실된 예가 없었다.

이상의 결과로 미루어 볼 때 본 연구에서 구현한 새로 운 척수강내 카테터 삽관수술은 랫드에서 장기적이고 안 정적으로 척수강내 약물투여가 가능할 것으로 사료된다. 이를 통해 전임상 연구시 척수내에서의 약물의 작용기전 및 약효를 검증하는데 유용할 것으로 판단된다. 


\section{참고문헌}

Asato, F., Butler, M. and Blomberg, H. (2001) Distribution of intrathecal catheter positions in rat. Acta Anaesthesiol. Scand. 45, 608-611.

Dib, B. (1984) Intrathecal chronic catheterization in the rat Pharmacol. Biochem. Behav. 20, 45-48.

Hylden, J.L. and Wilcox, GL. (1980) Intrathecal morphine in mice: a new technique. Eur. J. Pharmacol. 67, 313-316.

Martin, $H_{1}$, Kocher, L. and Chery-Croze, S. (1984) Chronic lumbar intrathecal catheterization in the rat with reducedlength spinal compression. Physiol. Behav. 33, 159-161.

Milligan, E.D., Hinde, J.L., Mehmert, K.K., Maier, S.F. and Watkins, L.R. (1999) A method for increasing the viability of the external portion of lumbar catheters placed in the spinal subarachnoid space of rats. J. Neurosci. Methods 90, 81-86.

Nahm, S. and Kim, Y.C. (2009) The intrathecal drug administration system. Korean J. Pain 22, 117-123.
Poon, Y.Y., Chang, A.Y., Ko, S.F. and Chan, S.H. (2005) An improved procedure for catheterization of the thoracic spinal subarachnoid space in the rat. Anesth. Analg. 101, 155-160.

Serpell, M.G., DeLeo, J.A. and Coombs, D.W. (1993) Intrathecal catheterization alone reduces autotomy after sciatic cryoneurolysis in the rat. Life Sci. 53, 1887-1892.

Storkson, R.V., Kjorsvik, A., Tjolsen, A. and Hole, K. (1996) Lumbar catheterization of the spinal subarachnoid space in the rat. J. Neurosci. Methods 65, 167-172.

Tsang, B.K., He, Z., Ma, T., Ho, I.K. and Eichhorn, J.H. (1997) Decreased paralysis and better motor coordination with microspinal versus PE10 intrathecal catheters in pain study rats. Anesth. Analg. 84, 591-594.

$\mathrm{Xu}, \mathrm{F}, \mathrm{Li}, \mathrm{T}$. and Zhang, B. (2009) An improved method for protecting and fixing the lumbar catheters placed in the spinal subarachnoid space of rats. J. Neurosci. Methods 183, 114-118.

Yaksh, T.L. and Rudy, T.A. (1976) Chronic catheterization of the spinal subarachnoid space. Physiol. Behav. 17, 1031-1036. 